\title{
КОНСЕРВАТИВНЕ ЛІКУВАННЯ СТРЕСОВОГО НЕТРИМАННЯ СЕЧІ У ЖІНОК ЗА ДОПОМОГОЮ ЕЛЕКТРОСТИМУЛЯЦІї З ОЦІНКОЮ ОТРИМАНИХ РЕЗУЛЬТАТІВ
}

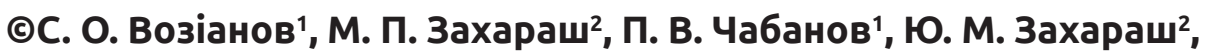 \\ Н. А. Севастьянова ${ }^{1}$, В. Ю. Угаров ${ }^{1}$, А. С. Репринцева ${ }^{3}$ \\ ДУ «Інститут урології НАМН України», Київ ${ }^{1}$ \\ Національний медичний університет імені О. О. Богомольця, Київ ${ }^{2}$ \\ КНП «Центр первинної медико-санітарної допомоги № 2» Солом'янського району, Київ
}

РЕзЮМЕ. Мета дослідження - підвищення ефективності лікування жінок із стресовим нетриманням сечі.

Матеріал і методи. Обстежено 87 жінок зі стресовим нетриманням сечі. Для визначення функціонального стану нервово-м'язового апарату нижніх сечовивідних шляхів використовували електроміографію сечового міхура і його сфінктерного апарату та урофлоуметрію.

Результати. При лікуванні жінок зі зниженим тонусом нервово-м'язових структур нижніх сечових шляхів за допомогою електростимуляції отримано позитивний ефект в 79,2 \% хворих, що підтверджується поліпшенням клінічної картини і результатами електроміографії та урофлоуметрії.

Висновки. Лікування пацієнтів зі стресовим нетриманням сечі за допомогою електростимуляції $є$ ефективним.

КлючОВІ СлОВА: стресове нетримання сечі; електростимуляція; електроміографія; урофлоуметрія.

Вступ. Нетримання сечі (НС), або інконтиненція, - клінічний симптом, який свідчить про порушення функції нижніх сечових шляхів і супроводжує різні за своїм ґенезом патологічні стани організму $[1,2]$.

Проблема НC $\epsilon$ найактуальнішою у жінок внаслідок значної поширеності серед жіночого населення. Це пояснюється анатомо-топографічними і фізіологічними особливостями жіночого організму [3-7]. НС не загрожує життю людини, однак пацієнтки страждають не тільки фізично, а й психоемоційно, що призводить до обмеження їх соціальної активності та істотно знижує якість життя. Найпоширенішим типом НС $\in$ стресова форма нетримання сечі (НC). Тому важливий пошук нових підходів до лікування цієї патології [8-10].

Мета - підвищення ефективності лікування жінок із стресовим НС.

Матеріал і методи дослідження. У дослідження було включено 87 жінок зі стресовим НС.

Для визначення функціонального стану м'язів, які забезпечують динамічну активність нижніх сечових шляхів (НСШ), використовували електроміографію (ЕМГ) сечового міхура та його сфінктерного апарату та урофлоуметрію (УФМ).

Усі уродинамічні обстеження хворих проводили на апараті MERCUR 4000 німецької фірми WIEST. Це обладнання дозволяє виконувати повний комплекс уродинамічних обстежень, дані яких одразу обробляються і видаються у вигляді графіка з відповідними цифровими характеристиками. Урофлоуметрія $\epsilon$ найпростішим методом дослідження уродинаміки НСШ як для лікаря, так і для хворого. Метод дає інформацію про загальну функцію
НСШ з виведення сечі. Спеціальної підготовки пацієнта для цього обстеження не потрібно.

Електроміографія (ЕМГ) - це графічна реєстрація біоелектричної активності м'язів, що використовується для якісної і кількісної оцінки функції м'язів, які забезпечують динамічну активність нижніх сечових шляхів. Для цього ми використовували ЕМГ сечового міхура і сфінктерного апарату. Для підсилення біоелектричної активності м'язів нижніх відділів сечової системи використовували електроміограф 4-канальний фірми «Медікор» (Угорщина).

Під час лікування для проведення електростимуляції хвору укладали на спину, процедуру проводили з порожнім сечовим міхуром електростимулятором із застосуванням двох пластинчастих електродів, змочених фізіологічним розчином, один з яких розташовували на рівні хребців S2-S4 перпендикулярно до хребта, інший - у нижній ділянці живота над лобком.

Результати й обговорення. ЕМГ м'язових структур сечового міхура визначила середнє значення різниці біопотенціалів детрузора - $(23,4 \pm$ $1,2)$ мкВ, на внутрішньому сфінктері сечового міхура - $(19,6 \pm 1,2)$ мкВ, на зовнішньому сфінктері $(34,7 \pm 1,8)$ мкВ. Ці ж показники у контрольній групі були такими: середнє значення різниці біопотенціалів детрузора - $(33,5 \pm 1,0)$ мкB, внутрішнього сфінктера сечового міхура - $(29,2 \pm 1,0)$ мкВ, зовнішнього сфінктера - $(41,6 \pm 2,0)$ мкВ. Урофлоуметрія у хворих вказала, що середнє значення основних показників було таким: об'єм сечовипускання (V) склав $(493,0 \pm 7,5)$ мл, час сечовипускання (T) $(37,1 \pm 1,6)$ с, максимальна о6'ємна швидкість потоку сечі (Qmax) - $(14,5 \pm 1,3)$ мл/с, середня швидкість 
Огляди літератури, оригінальні дослідження, погляд на проблему, випадок з практики, короткі повідомлення сечовипускання (Qave) - $(13,3 \pm 1,33)$ мл/с, час досягнення максимальної швидкості (TQ max) - $(9,1 \pm$ $1,1)$ с. Середня швидкість сечовипускання в контрольній групі склала $(15,8 \pm 1,3)$ мл/с, що, порівняно з показниками до лікування, $\epsilon$ достовірним $(p<0,05)$.

Ефективність лікування ми оцінювали після першого, третього та шостого курсів лікування, в результаті оцінювання ми отримали наступні дані.

Після першого курсу лікування при оцінці показників ЕМГ м'язових структур сечового міхура ми отримали таке середнє значення різниці біопотенціалів: детрузора - $(24,8 \pm 1,4)$ мкВ, де покращення склало 5,6 \%, на внутрішньому сфінктері сечового міхура - $(22,3 \pm 1,5)$ мкВ, $12,1 \%$, на зовнішньому сфінктері $(35,1 \pm 1,7)$ мкВ, 1,1 \% відповідно.

Що стосується динаміки змін показників УФМ, ми отримали наступне, а саме - об'єм сечовипускання (V) склав $(442,0 \pm 6,8)$ мл, $11,5 \%$, час сечовипускання (T) - $(30,1 \pm 1,5)$ с, 23,3 \%, максимальна

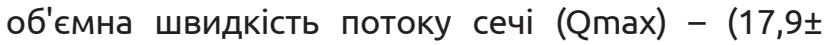
$1,4)$ л/с, $19 \%$, середня швидкість сечовипускання (Qave) - $(14,7 \pm 1,3)$ мл/с, 9,5 \%, час досягнення максимальної швидкості (TQmax) - $(10,4 \pm 1,2)$ с, 12,5 \% відповідно.

За результатами третього курсу лікування нами були отримані наступні показники різниці біопотенціалів м'язових структур сечового міхура

та його сфінктерного апарату: детрузора $(26,5 \pm 1,3)$ мкВ, де покращення склало 11,7 \%, на внутрішньому сфінктері сечового міхура $(25,7 \pm 1,2)$ мкВ $23,7 \%$, на зовнішньому сфінктері $(37,8 \pm 1,8)$ мкВ, 8,2 \% відповідно.

Показники УФМ після третього курсу лікування були наступними: об'єм сечовипускання (V) склав $(391 \pm 6,7)$ мл, 26,1\%, час сечовипускання (T) $(24,5 \pm 1,3)$ с, 51,4 \%, максимальна об'ємна швидкість потоку сечі (Qmax) - $(18,8 \pm 1,3)$ мл/с, 22,9 \%, середня швидкість сечовипускання (Qave) $(16,1 \pm 1,1)$ мл/с, 17,4 \%, час досягнення максимальної швидкості (TQ max) - $(11,1 \pm 1,2)$ с, $18 \%$.

Після завершення шести курсів лікування виявлено значне покращення як клінічних даних, так і результатів ЕМГ та УФМ. Різниця біопотенціалів м'язових структур сечового міхура та його

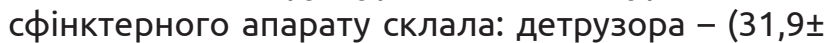
$1,5)$ мкВ, де покращення склало 26,6 \%, ( $p<0,05)$; на внутрішньому сфінктері сечового міхура $(28,9 \pm 1,4)$ мкB, 32,2 \%, ( $p<0,05)$; на зовнішньому сфінктері - $(40,2 \pm 2,0)$ мкВ, 13,7 \% (p<0,05). При порівнянні цих показників із контрольною групою середнє значення різниці біопотенціалів детрузора було $(33,5 \pm 1,0)$ мкВ $(p<0,05)$, внутрішнього сфінктера сечового міхура - $(29,2 \pm 1,0)$ мкВ $(p<0,05)$, зовнішнього сфінктера - $(41,6 \pm 2,0)$ мкВ $(p<0,05)$ (рис. 1).

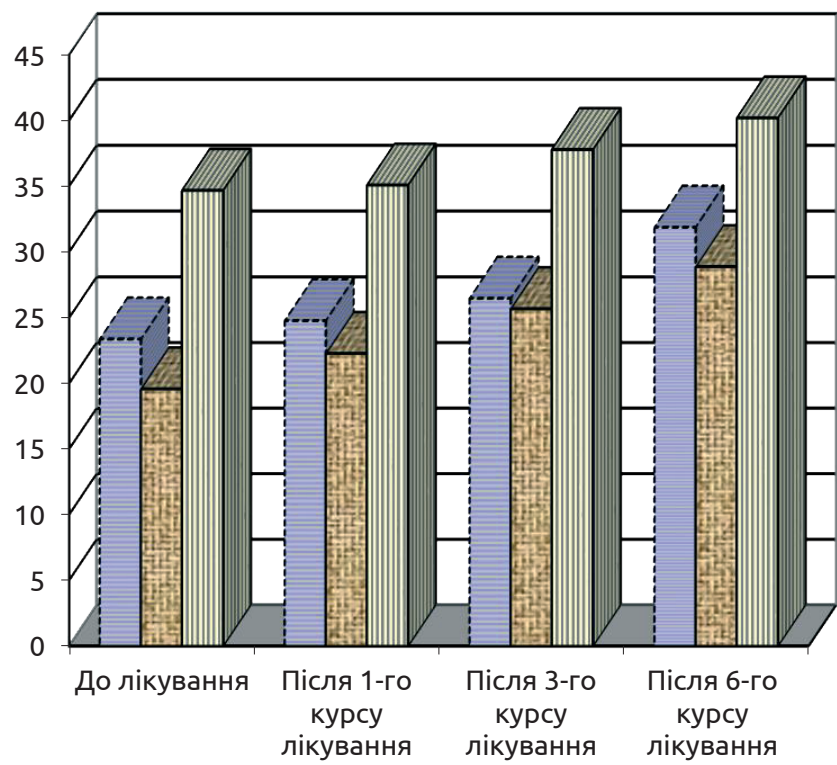

巨детрузор

๑Внутрішній сфінктер

ஐЗовнішній сфінктер

Рис. 1. Динаміка змін показників електроміографії сечового міхура та його сфінктерного апарату у жінок зі стресовим нетриманням сечі, мкВ.

Показники УФМ після шостого курсу лікування такі: об'єм сечовипускання (V) склав $(331 \pm 6,2)$ мл, 48,9\% ( $<<0,001)$, час сечовипускання (Т) $(18,7 \pm 1,2)$ c, 98,4 \%, (p<0,05), максимальна об'ємна швидкість потоку сечі (Qmax)
$(24,6 \pm 1,4)$ мл/с, 41,0 \%, ( $p<0,05)$, середня швидкість сечовипускання (Qave) $(17,1 \pm 1,2)$ мл/с, $22,2 \%,(p<0,05)$, час досягнення максимальної швидкості (TQ max) - $(11,9 \pm 0,85)$ c, 23,5 \% $(p<0,05)$ (рис. 2). 
Огляди літератури, оригінальні дослідження, погляд на проблему, випадок з практики, короткі повідомлення
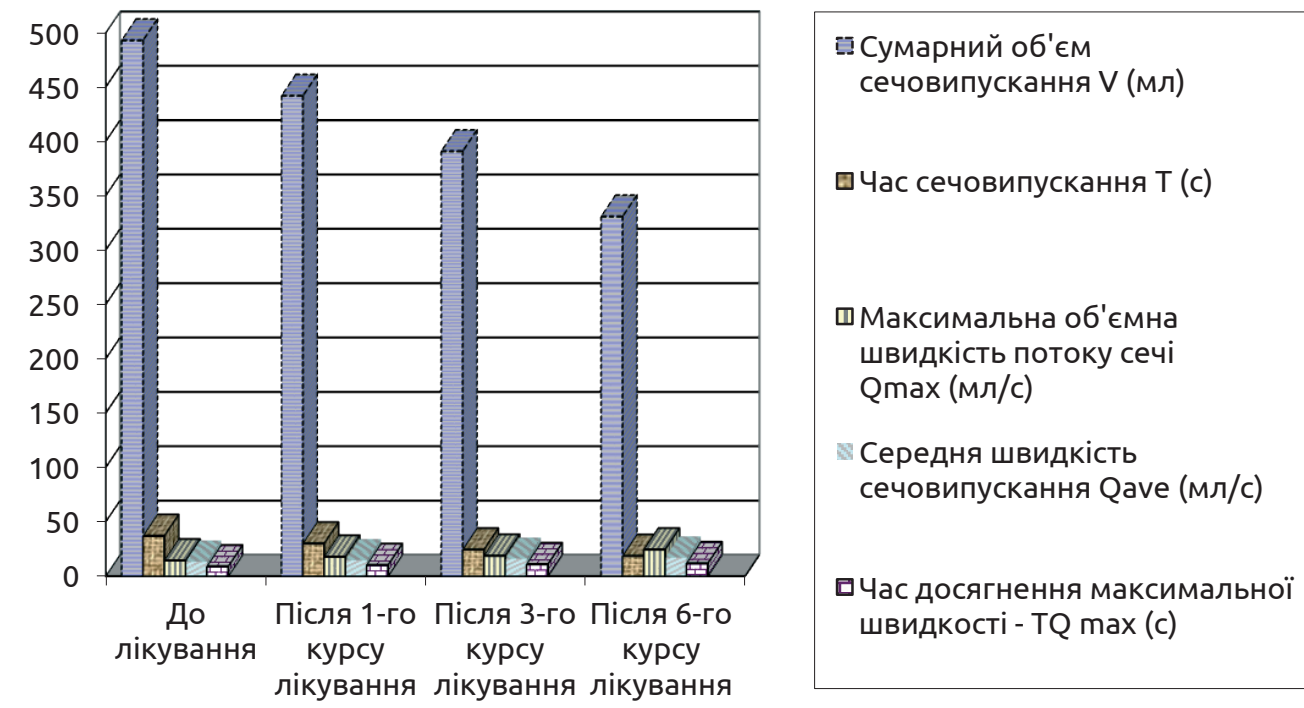

ஐЧас досягнення максимальної швидкості - TQ $\max (c)$

Рис. 2. Динаміка змін показників урофлоуметрії у жінок зі стресовим нетриманням сечі.

При лікуванні жінок зі зниженим тонусом нервово-м'язових структур нижніх сечових шляхів за допомогою електростимуляції отримано позитивний ефект у 79,2 \% хворих, що підтверджується покращенням клінічної картини та результатами електроміографії, урофлоуметрії. Наведені дані дозволяють зробити висновок, що ефективність електричної стимуляції у жінок зі стресовим НС знаходиться в прямій залежності від ступеня зниження показників нервовом'язових структур детрузора, тобто, чим нижче ці показники, тим менший відсоток ефективності проведеного лікування. Навпаки, при меншому ступені зниження тонусу цих нервово-м'язових структур відсоток одужання вищий.

Висновки. Наведені вище дані дозволили розробити патогенетично обґрунований метод лікування стресового НС за допомогою електростимуляції в залежності від стану нервово-м'язових структур нижніх сечових шляхів. ЕМГ та УФМ $\epsilon$ об'єктивними критеріями для діагностики та оцінки ефективності лікування.

\section{ЛІТЕРАТУРА}

1. Взаємозв'язок між станом детрузора і тонусом товстої кишки та їхнім сфінктерним апаратом у жінок з гіперактивним сечовим міхуром / С. О. Возіанов М. П. Захараш, П. В. Чабанов [та ін.] // Здоровье женщины. 2017. - № 8 (124). - С. 32-34.

2. An International Urogynecological Association (IUGA)/International Continence Society (ICS) joint report on the terminology for the conservative and nonpharmacological management of female pelvic floor dysfunction / K. Bo, H. C. Frawley, B. T. Haylen [et al.] // Neurourol. Urodyn. - 2017. - Vol. 36 (2). - P. 221-244.

3. Prevalence, impact and specialised treatment of urinary incontinence inwomenwith chronic lung disease / B. M. Button, A. E. Holland, M. S. Sherburn [et al.] // Physiotherapy. - 2019. - Vol. 105 (1). - P. 114-119. DOI: 10.1016/j. physio.2018.07.0Q6.

4. Sacral nerve modulation for defaecation and micturition disorders in patients with spina bifida / S. M. Lansen-Koch, B. Govaert, D. Oerlemans [et al.] // Colorectal Dis. - 2012. - Vol. 14 (4). - P. 508-514. DOI: $10.1111 /$ j.1463-1318.2011.02678.x.
5. Diagnosis and treatment of overactive bladder (Non-Neurogenic) in adults: AUA/SUFU Guideline Amendment / E. A. Gormley, D. J. Lightner, M. Faraday, S. P. Vasavada // J. Urol. - 2015. - Vol. 193 (5). - P. 1572-1580. DOI: $10.1097 / \mathrm{JU} .0000000000000309$.

6. Fiodorenko-Dumas Z. Post-powanie fizjoterapeutyczne w nietrzymaniu moczu / Z. Fiodorenko-Dumas, M. Paprocka-Borowicz // MONZ. - 2014. - Vol. 20. - P. 12-16.

7. Hrycyna M. Cwiczenia wzmacniajace mieSnie dna miednicy mniejszej u kobiet z wysikowym nietrzymaniem moczu / M. Hrycyna, E. Strupiriska-Thor // Zeszyty Naukowe WSK-FiT. - 2016. - Vol. 11. - P. 21-28.

8. EAU Guidelines on Assessment and Nonsurgical Management of Urinary Incontinence / A. K. Nambiar, R. Bosch, F. Cruz [et al.] // Eur. Urol. - 2018. - Vol. 73 (4). P. 596-609.

9. NICE. Urinary incontinence and pelvic organ prolapse in women: management. NICE guideline [NG123]. 2019. - Apr. 2.

10. Syan R. (2015). Guideline of guidelines: urinary incontinence / R. Syan, B. M. Brucker. BJU Int., 117 (1). DOI: https://doi.org/10.1111/bju.13187. 
Огляди літератури, оригінальні дослідження, погляд на проблему, випадок з практики, короткі повідомлення REFERENCES

1. Vozianov, S.A., Zakharash, M.P., Zakharash, Yu.M., Sevastyanova, N.A., Chabanov, P.V., Uharov, V.Yu., \& Repryntseva, A.S. (2017). Vzaiemozviazok mizh stanom detruzora i tonusom tovstoi kyshky ta yikhnim sfinkternym aparatom u zhinok z hiperaktyvnym sechovym mikhurom [The relationship between the state of the detrusor and the tone of the colon and their sphincter apparatus in women with hyperactive bladder]. Zdorovie zhenshchynyWomen's Health, 8 (124), 32-34 [in Ukrainian].

2. Bo, K., Frawley, H.C., Haylen, B.T., Abramov, Y., Almeida, F.G., Berghmans, B., ..., \& Wells, A. (2017). An International Urogynecological Association (IUGA)/International Continence Society (ICS) joint report on the terminology for the conservative and nonpharmacological management of female pelvic floor dysfunction. Neurourol. Urodyn, 36 (2), 221-244. DOI: 10.1002/nau.23107.

3. Button, B.M., Holland, A.E., Sherburn, M.S., Chase, J., Wilson, J.W., \& Burge, A.T. (2019). Prevalence, impact and specialised treatment of urinary incontinence inwomenwith chronic lung disease. Physiotherapy, 105 (1), 114-119. DOI: 10.1016/j,physio.2018.07.0Q6.

4. Lansen-Koch, S.M., Govaert, B., Oerlemans, D., Melenhorst, J., Vles, H., Cornips, E., ..., \& van Gemert, W.G. (2012). Sacral nerve modulation for defaecation and micturition disorders in patients with spina bifida. Colorectal
Dis., 14 (4), 508-514. DOI: 10.1111/j.1463-1318.2011. 02678.x.

5. Gormley, E.A., Lightner, D.J., Faraday, M., \& Vasavada, S.P. (2015). Diagnosis and treatment of overactive bladder (Non-Neurogenic) in adults: AUA/SUFU Guideline Amendment. J. Urol., 193 (5), 1572-1580. DOI: 10.1097/ JU.0000000000000309.

6. Fiodorenko-Dumas, Z., \& Paprocka-Borowicz, M. (2014). Post-powanie fizjoterapeutyczne w nietrzymaniu moczu. MONZ, 20, 12-16.

7. Hrycyna, M., \& Strupiriska-Thor, E. (2016). Cwiczenia wzmacniajace mieSnie dna miednicy mniejszej u kobiet z wysikowym nietrzymaniem moczu. Zeszyty Naukowe WSK-FiT, 11, 21-28.

8. Nambiar, A.K., Bosch, R., Cruz, F., Lemack, G.E., Thiruchelvam, N., Tubaro, A., ..., \& Burkhard, F.C. (2018). EAU Guidelines on Assessment and Nonsurgical Management of Urinary Incontinence. Eur. Urol., 73 (4), 596-609.

9. NICE. (2019). Urinary incontinence and pelvic organ prolapse in women: management. NICE guideline [NG123], Apr. 2.

10. Syan, R., \& Brucker, B.M. (2015). Guideline of guidelines: urinary incontinence. BJU Int., 117 (1). DOI: https://doi.org/10.1111/bju.13187.

\title{
CONSERVATIVE TREATMENT OF STRESS URINARY INCONTINENCE IN WOMEN USING ELECTRICAL STIMULATION AND EVALUATION OF THE RESULTS OBTAINED
}

\author{
OS. O. Vozianov' ${ }^{1}$, M. P. Zakharash², P. V. Chabanov', Yu. M. Zakharash'², \\ N. A. Sevastyanova', V. Yu. Ugarov', A. S. Reprintseva ${ }^{3}$ \\ Institute of Urology of the National Academy of Medical Sciences of Ukraine, Kyiv ${ }^{1}$ \\ O. O. Bohomolets National Medical University, Kyiv² \\ "Center for Primary Health Care No. 2" Solomenskyi district, Kyiv
}

SUMMARY. The aim - to improve the effectiveness of treatment for women with stress urinary incontinence.

Material and Methods. 87 women with stress urinary incontinence were examined. To determine the functional state of the neuromuscular apparatus of the lower urinary tract, electromyography of the bladder and its sphincter apparatus and uroflowmetry were used.

Results. When treating women with decreased tone of the neuromuscular structures of the lower urinary tract using electrical stimulation, a positive effect was obtained in $79.2 \%$ of patients, which is confirmed by an improvement in the clinical picture and the results of electromyography and uroflowmetry.

Conclusions. Treatment of patients with stress urinary incontinence with electrical stimulation is effective.

KEY WORDS: stress urinary incontinence; electrical stimulation; electromyography; uroflowmetry.

Отримано 20.08.2021 